REVIEW ARTICLE

\title{
A review of the diversity of aquatic avifauna in Mizoram, India
}

\author{
Christopher John Zomuana Lawlor ${ }^{1,2^{*}}$ and H. Lalthanzara ${ }^{2}$ \\ ${ }^{1}$ Department of Zoology, Government Kolasib College, Kolasib 796081, Mizoram \\ ${ }^{2}$ Department of Life Sciences, Pachhunga University College, Mizoram University, Aizawl 796001, Mizoram
}

\begin{abstract}
Aquatic avifauna are an important bio-indicator of an ecosystem changes. Mizoram, one of the north-eastern states of India, lies in one of the richest biodiversity hotspots of the world. Along its water bodies, it is home to several species of resident birds, and is also a temporary home for migrating birds in different seasons. These resident and migratory avifauna form an important component of most wetland ecosystems, as they are vital components of the food webs. While only the Tamdil and Palak Lake are recognized as wetlands, there are several rivers and smaller water bodies around which aquatic avifauna exist. However, official records comprise of about 14 species of waterbirds belonging to 6 orders and 8 families. Of these, Anatidae, Charadriidae, Scolopacidae, Anhingidae, and Podicipedidae are represented by one species each, while the Ardeidae are represented by four species. Among the 14 species reported so far, two species of the Order Pelicaniformes, namely Anhinga melanogaster (Family Anhingidae) and Ardea insignis (Family Ardeidae) are highly endangered. However, detailed studies are wanting and, while there are sporadic reports of sightings on social media, there is a need for a more comprehensive study of the diversity and seasonal variations of aquatic avifauna around the different water bodies of the state of Mizoram.
\end{abstract}

Keywords: Mizoram, avifauna, diversity, waterbirds, wetlands, lakes, rivers.

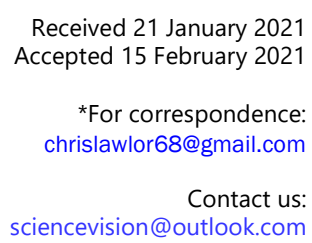

\section{Introduction}

As defined by Article 1.2 of the Convention on Wetlands (Ramsar, Iran, 1971) ${ }^{1}$, wetlands include a wide variety of habitats such as marshes, peatlands, floodplains, rivers and lakes, and coastal areas such as saltmarshes, mangroves, and seagrass beds, but also coral reefs and other marine areas no deeper than six metres at low tide, as well as human-made wetlands such as waste-water treatment ponds and reservoirs.

For the purposes of the International Waterbird Census, all species in the following families are considered by Wetlands International to be waterbirds: Gaviidae (Divers/Loons), Podicipedidae (Grebes), Pelecanidae (Pelicans), Phalacrocoracidae (Cormorants), Anhingidae (Darters), Ardeidae (Herons), Scopidae (Hamerkop), Ciconiidae (Storks), Balaenicipitidae (Shoebill), Ciconiidae (Storks), Threskiornithidae (Ibises and Spoonbills), Phoenicopteridae (Flamingos), Anhimidae (Screamers), Anatidae (Ducks, Geese and Swans), Gruidae (Cranes), Aramidae (Limpkin), Rallidae (Rails, Gallinules and Coots), Heliornithidae (Finfoots), Eurypygidae (Sunbittern), Jacanidae (Jacanas), Rostratulidae (Painted Snipes), Dromadidae (Crab 
Plover), Haematopodidae (Oystercatchers), Ibidorhynchidae (Ibisbill), Recurvirostridae (Stilts and Avocets), Burhinidae (Thick-knees), Glareolidae (Coursers and Pratincoles), Charadriidae (Plovers), Scolopacidae (Sandpipers, Snipes and Phalaropes), Pedionomidae (Plains Wanderer), Thinocoridae (Seedsnipes), Laridae (Gulls), Sternidae (Terns) and Rynchopidae (Skimmers). Only a few wetland birds are excluded by considering entire families in this way. On the other hand, the inclusion of whole families results in the waterbird list containing a few non-wetland species such as some coursers and thick-knees. The Ramsar Convention on Wetlands has widened its approach to include more families traditionally regarded as seabirds, as well as certain raptors and passerines, and it is possible that a small number of additions will be made in the coming years to the families and species included in the IWC. ${ }^{1}$

India is one of the seventeen mega-diverse countries in the world. Though having only $2.4 \%$ of the world's total land area, India harbours $9.13 \%$ of the flora and $6.7 \%$ of the fauna of the world, including $12.6 \%$ of the world's avian species. Of the four biodiversity rich regions of India, the North Eastern region of India is one of the richest biodiversity regions, and is a part of the Indo-Burma hotspot (Puri).

Mizoram is situated in the North-Eastern region of India, along with its sister states, namely, Manipur, Nagaland, Tripura, Arunachal Pradesh, Assam, and Meghalaya. It has an international boundary with Myanmar in the eastern part and Bangladesh in the western part. Besides, it is bounded with the neighboring states, viz., Assam, Manipur and Tripura. Mizoram is endowed with dense forests and diverse species of the flora and fauna. It has also a rich diversity of medicinal plants having high value for the treatment of various illnesses.

\section{Geography of the State}

\section{Boundary and topography}

Mizoram lies between latitudes $21^{\circ} 56^{\prime} \mathrm{N}$ and $24^{\circ}$ $31^{\prime} \mathrm{N}$ (285 kilometers north to south) and spans across $92^{\circ} 16^{\prime} \mathrm{E}$ to $93^{\circ} 26^{\prime} \mathrm{E}$ longitude (115 kilometers east to west), covering an area of about 21,087 square kilometers (Pachuau, 1994). ${ }^{3}$ Being a land of rolling hills, valleys, rivers and lakes, there are as many as 21 major hill ranges or peaks of different heights that run through the length and breadth of the state, with low-lying plains in between. Hills to the west of the state average in height of about 1,000 metres $(3,300 \mathrm{ft})$, gradually rising up to 1,300 metres $(4,300 \mathrm{ft})$ towards the east. Phawngpui Tlang, also known as the Blue Mountain, situated in the southeastern part of the state, is the highest peak in Mizoram at 2,210 metres $(7,250 \mathrm{ft})$. About $76 \%$ of the state is covered by forests, $8 \%$ is fallow land, $3 \%$ is barren and considered uncultivable, while cultivable and sown area constitutes the rest.

\section{Physiography}

Mizoram is comprised of rugged, steep hill ranges and interspersed valleys. The state has a climate ranging from moist tropical to moist subtropical. The annual rainfall ranges between 2,100 $\mathrm{mm}$ to $3,500 \mathrm{~mm}$ and the annual temperature during winter, $11^{\circ} \mathrm{C}$ to $24^{\circ} \mathrm{C}$ and in summer between $18^{\circ} \mathrm{C}$ to $29^{\circ} \mathrm{C}$. It rains heavily from May to September.

\section{Vegetation and forest cover}

According to the 2019 Indian State of Forest Report ${ }^{4}$, Mizoram has the third highest total forest cover among the different states of India in terms of percentage of geographical area. However, satellite imagery indicates a gradual reduction in forest cover from 19,117 square kilometers (90.68\%) as in January 2009 , to $18,005.51$ square kilometers $(85.41 \%$ of the State's geographical area) in February 2018.

As per the Champion and Seth Classification of Forest Types of 1968, the forests in Mizoram belong to four Type Groups, which can be further divided into six Forest Types. Tropical wet-evergreen forests of the State have valuable species in the top canopy such as Dipterocarpus turbinatus, Artocarpus chaplasha, Terminalia myriocarpa, Amoora wallichii, Michelia champaca, Mesua ferrea, etc. Bamboos occur abundantly in the middle and lower stories in the evergreen forest type, canes are also present in this type of forest. Twenty seven species of bamboo are reported from the State, between 400 to 1500 metres elevation, of which the most common is Melocanna baccifera. ${ }^{6}$ Approximately 9,245 km2 (44\%) of the state's area is bamboo bearing.

The eastern fringes of the State bordering Chin Hills of Myanmar are higher in elevation and fall under Montane subtropical pine forests. This region is relatively cooler and experiences less annual precipitation. The common species of montane subtropical pine forests include Pinus kesiya, Quercus sp., Castanopsis sp., Schima wallichii, Rhododendron arboreum, Rhus semialata etc.

\section{Wetlands}

According to the National Wetland Atlas of Mizoram (2011), the State possesses 88 wetlands, with a total estimated wetland area of 13,988 ha. Of this, 13,497 ha is covered by rivers/streams which form major wetlands in the State, while lakes/ponds, water logged area, reservoirs and small wetlands account for 491 ha. $^{7}$

While all the districts of the state have wetlands, the largest area covered is in Lunglei district $(3,186$ ha), while Kolasib district has just an area of 884 ha of wetland ${ }^{7}$. The only man-made wetland (reservoir) 
Table 1 | Wetlands inside the Recorded Forest Area (or Green Wash) in Mizoram. (Source: India State of Forest Report 2019, Mizoram. Analysis based on the National Wetlands Atlas, 2011)

\begin{tabular}{|c|c|c|c|c|}
\hline $\begin{array}{l}\text { Sl. } \\
\text { No. }\end{array}$ & $\begin{array}{l}\text { Wetland } \\
\text { Code }\end{array}$ & Wetland Category & No. of Wetlands & $\begin{array}{c}\text { Total Wetland Area (in } \\
\text { ha) }\end{array}$ \\
\hline & 1100 & \multicolumn{3}{|c|}{ Inland Wetlands - Natural } \\
\hline 1 & 1101 & Lake/Pond & 25 & 185 \\
\hline 2 & 1102 & Ox-bowlake/Cut-offmeander & - & - \\
\hline 3 & 1105 & Waterlogged & 15 & 133 \\
\hline \multirow[t]{2}{*}{4} & 1106 & River/ Stream & 46 & 13,497 \\
\hline & 1200 & \multicolumn{3}{|c|}{ Inland Wetlands - Man-made } \\
\hline 5 & 1201 & Reservoir/ Barrage & 2 & 27 \\
\hline \multirow[t]{4}{*}{6} & & Wetlands (<2.25ha) & 146 & 146 \\
\hline & & Total & 234 & 13,988 \\
\hline & & Total Recorded Forest (or Green & (in ha) & $20,66,283$ \\
\hline & & $\%$ of Wetland area inside Recor & rGreen Wash) Area & $0.60 \%$ \\
\hline
\end{tabular}

is located in Mamit district (namely, Rengdil). ${ }^{6}$

\section{Rivers}

The biggest river in Mizoram lies to the south, and is called Chhimtuipui or Kaladan (or Kolodyne). It originates in Chin state in Burma, and after passing through Saiha and Lawngtlai districts in the southern tip of Mizoram, goes back to Burma's Rakhine state. It has four tributaries and the western part is drained by Karnaphuli (Khawthlang tuipui) and its tributaries.

Although many rivers and streams drain the hill ranges, the most important and useful rivers are the Tlawng (also known as Dhaleswari or Katakhal in Assam), Tut, Tuirial (Sonai), and Tuivawl, which flow through the northern parts of the state and eventually join the Barak River in Cachar District of Assam. The rivers have a gentle drainage gradient particularly in the south.

\section{Lakes}

There are several small lakes scattered in different parts of the state. The larger lakes and those of more prominence are Palak, Tamdil, Rungdil, and Rengdil. Palak lake is situated in Saiha District in southern Mizoram $\left(22^{\circ} 12^{\prime} 10.89^{\prime \prime} \mathrm{N}\right.$ 92 ${ }^{\circ} 53^{\prime} 18.18^{\prime \prime} \mathrm{E}$ at $279 \mathrm{~m}$ asl), $130 \mathrm{~km}$ south-west of Saiha. It is an oval lake, $200 \mathrm{~m}$ long and $150 \mathrm{~m}$ wide, covering an area of 30 hectares (74 acres). It is believed the lake was created as a result of an earthquake or a flood. The local people believe a village which was submerged still remains intact deep under the waters. Tamdil is a natural lake situated in Saitual District $\left(\left(23^{\circ} 41^{\prime} 19.68^{\prime \prime} \mathrm{N} 92^{\circ} 57^{\prime} 10.53^{\prime \prime} \mathrm{E}\right.\right.$ at $766 \mathrm{~m}$ asl $)$, and is an important tourist attraction and a holiday resort.

Rungdil is situated $14 \mathrm{~km}$ from Suangpuilawn village in Aizawl district. It has an area of 2.5 hectares. Rungdil means lake of partridge, as at one time it was the habitat of a large number of partridges. It consists of two lakes, more or less alike, separated by a narrow stretch of land, and are believed to have a subterranean connection. The lake is surrounded by tropical evergreen deciduous forests. Rengdil is a man-made or artificial lake, situated in Mamit district, $150 \mathrm{~km}$ to the north-west of Aizawl and about $8 \mathrm{~km}$ from Zamuang village.

\section{Avian fauna}

Mizoram is host to numerous species of fauna and flora. The Zoological Survey of India conducted a detailed study of the state, reporting nearly 1468 species belonging to 891 genera under 295 families, of which insects alone form 37\% with 520 species, the next abundant group is the birds with nearly 370 species and subspecies (Fauna of Mizoram, 2007). ${ }^{8}$

Through initial surveys of avian diversity from the works of Ali and Ripley $(1987)^{9}$ till more recent studies, most of the works in north-east India relate to Assam, Arunachal, and Manipur. It is only more recently that some surveys and detailed studies have been made in the state of Mizoram. ${ }^{10-20}$

In another report, about 640 species of birds have been identified in the state, many of which are endemic to the Himalayan foothills and southeast Asia. According to the Avibase website, of the birds found in Mizoram forests, 28 are on the worldwide threatened species lists and eight are on the critically endangered list. $^{22}$ Prominent birds spotted in Mizoram include those from the families of Phasianidae, Anatidae, Ciconiidae, Threskiornithidae, Ardeidae, Pelecanidae, Phalacrocoracidae, Falconidae, Accipitridae, Otididae, Rallidae, Heliornithidae, Turnicidae, Burhinidae, Charadriidae, Scolopacidae, Jacanidae, Laridae, Columbidae, 
Table 2 | List of aquatic avifauna reported in Mizoram. (*Conservation status according to IUCN Red List ${ }^{25}$ : LC Least Concern; NT - Near Threatened, VN - Vulnerable, EN - Endangered, CE - Critically Endangered)

\begin{tabular}{|c|c|c|c|c|c|}
\hline $\begin{array}{l}\text { SL. } \\
\text { No. }\end{array}$ & Species & $\begin{array}{l}\text { Common name } \\
\text { (Local name) }\end{array}$ & Order & Family & $\begin{array}{c}\text { Conserva } \\
\text { tion } \\
\text { status* }\end{array}$ \\
\hline 1. & $\begin{array}{l}\text { Dendrocygna } \\
\text { javanica }\end{array}$ & $\begin{array}{l}\text { Lesser whistling duck } \\
\text { (Tuivarak) }\end{array}$ & Anseriformes & Anatidae & LC \\
\hline 2. & Vanellus indicus & $\begin{array}{l}\text { Red-wattled lapwing } \\
\text { (Mangkhaia ralveng) }\end{array}$ & Charadriiformes & Charadriidae & LC \\
\hline 3. & Actitis hypoleucos & $\begin{array}{l}\text { Common sandpiper } \\
\text { (Chirhdawt) }\end{array}$ & Charadriiformes & Scolopacidae & LC \\
\hline 4. & Halcyon capensis & $\begin{array}{l}\text { Stork-billed kingfisher } \\
\text { (Kaikuangral lu-uk) }\end{array}$ & Coraciiformes & Alcedinidae & LC \\
\hline 5. & Halcyon smyrnensis & $\begin{array}{l}\text { White-breasted kingfisher } \\
\text { (Kaikuangral awrvar) }\end{array}$ & Coraciiformes & Alcedinidae & LC \\
\hline 6. & Alcedo atthis & $\begin{array}{l}\text { Common/ Small blue } \\
\text { kingfisher (Kaikuangrual } \\
\text { te) }\end{array}$ & Coraciiformes & Alcedinidae & LC \\
\hline 7. & Gallinula chloropus & Common moorhen (Rih-ar) & Gruiformes & Rallidae & LC \\
\hline 8. & Porphyrio porphyrio & $\begin{array}{l}\text { Western swamphen/ } \\
\text { Purple moorhen }\end{array}$ & Gruiformes & Rallidae & LC \\
\hline 9. & $\begin{array}{l}\text { Anhinga } \\
\text { melanogaster }\end{array}$ & Oriental darter (Varul) & Pelecaniformes & Anhingidae & NT \\
\hline 10. & Ardeola grayii & Indian pond heron & Pelecaniformes & Ardeidae & LC \\
\hline 11. & Ardea alba & GreatEgret & Pelecaniformes & Ardeidae & LC \\
\hline 12. & Ardea insignis & $\begin{array}{l}\text { White-bellied heron } \\
\text { (kawlpui saruh-hak) }\end{array}$ & Pelecaniformes & Ardeidae & CE \\
\hline 13. & Bubulcus ibis & Cattle Egret (Tuiva arngo) & Pelecaniformes & Ardeidae & LC \\
\hline 14. & $\begin{array}{l}\text { Trachybaptus } \\
\text { ruficollis }\end{array}$ & Little grebe & Phoenicopteriformes & Podicipedidae & LC \\
\hline
\end{tabular}

Psittacidae, Cuculidae, Strigidae, Caprimulgidae, Apodidae, Alcedinidae, Meropidae, Bucerotidae, Ramphastidae, Picidae, Pittidae, Laniidae, Campephagidae, Dicruridae, Corvidae, Paridae, Hirundinidae, Cisticolidae, Pycnonotidae, Sylviidae, Timaliidae, Sittidae, Sturnidae, Turdidae, Dicaedae, Chloropseidae, Ploceidae, Motacillidae, Fringillidae, Nectariniidae, and Muscicapidae.

\section{Aquatic avifauna}

Waterbirds are birds that are found close to water bodies, such as lakes, ponds, rivers, streams, and the like. They are sustained by the rich flora and fauna of their limited habitats.

The ENVIS Resource Partner on Avian Ecology (2014) recorded 235 species of waterbirds in India, and another 67 species of avifauna that are dependent upon the various wetlands. ${ }^{23}$ In Mizoram, so far studies and reports are scanty, and only a few reports have been made mostly from the southern parts of the state.

Over 70 species of birds were recorded from Palak lake during an Important Bird and Biodiversity Area (IBA) survey, ${ }^{11}$ though the bird life is certainly much richer. The Scottish naturalist Robertson reported on the avifauna of Palak lake, including the great Indian hornbill (Buceros bicornis), oriental pied hornbill (Anthracoceros albitrostis), Malabar pied hornbill (A. malabaricus), Courtois's laughingthrush (Garullex leucoluphus), grey peacock-pheasant (Polyplectron bicalcaratum), little grebe (Trachybaptus ruficollis), red junglefowl (Gallus gallus), Indian pond heron (Ardeola grayii), western swamphen (Porphrycio porphyrio), Eurasian hoopoe (Upupa epops). ${ }^{17}$

The presence of 136 species of avifauna and 42 species of mammals were recorded by Datta-Roy et al (2007). ${ }^{13}$ Palak lake is reported to be the only abode of aquatic birds, with wild duck of different species. ${ }^{24}$ Migratory birds are also mentioned to visit the lake. Choudhury (2006) reported a single 
sighting of a (Oriental) Darter (Anhinga melanogaster) at Palak. ${ }^{12}$

Lalthanzara and Kasambe have mentioned the following waterbirds in their book, Popular Birds of Mizoram (2015), namely, Anhinga melanogaster (Oriental darter; varul), Ardea insignis (white-bellied heron; kawlpui saruh-hak), Ardeola grayii (Indian pond heron; vacha/ tuivalawng), Phalacrocorax carbo (Great cormorant; tuivarak dum), Gallinula chloropus (Common moorhen; Rih-ar), Porphyrio porphyrio (Purple/Swamp moorhen; Dum-ar), Tachybaptus ruficollis (Little grebe; Dil-arte), Vanellus indicus (Red -wattled lapwing; Mangkhaia ralveng), Actitis hypoleucos (Common sandpiper; Chirhdawt), Halycon capensis (Stork-billed kingfisher; Kaikuangral lu-uk), Halycon smyrnensis (white-throated/breasted kingfisher; Kaikuangral awrvar), Alcedo atthis (Common/ Small blue kingfisher; Kaikuangrual te $)^{18}$. On reporting on the avifauna of Lungleng-I in Aizawl District of Mizoram, Lalthanzara and Sailo (2017) report the occurrence of Lesser Whistling Duck Dendrocygna javanica (Tuivarak) and Common Moorhen Gallinula chloropus (Rih-ar), among 114 species of 40 families of birds. ${ }^{17}$ While most of the reports and sightings have been made from Palak Lake in the south of Mizoram, there are no traceable records of reports from the northern parts of the state, such as from Serlui or Tuirial [Hydro-Electric Projects] in Kolasib District.

\section{Discussion}

While there are reports of over 640 species of birds in Mizoram, confirmable reports of aquatic avifauna number only about 14 species, mostly from Palak Lake in southern Mizoram. Confirmed reports comprised one species each of lesser whistling duck (Dendrocygna javanica), red-wattled lapwing (Vanellus indicus), common sandpiper (Actitis hypoleucos), and little grebe (Trachybaptus ruficollis) all of which are of less concern as to their conservation status, and the near threatened Oriental darter (Anhinga melanogaster). There are two species of swamphen (Gallinula chloropus, Porphrcio porphyrio), and they show stable populations. It is a similar situation with the three kingfisher species prevalent (Halcyon capensis, Halcyon smyrnensis, and Alcedo atthis), all which are classified as of being of least concern. There are four species of the large waders of Family Ardeidae (Ardeola grayii, Ardea alba, Ardea insignis, and Bubulcus ibis) reported in Mizoram, of which the White-bellied heron Ardea insignis is considered to be critically endangered. It may do well to mention that there are a few scanty and scattered reports in various social media sites, but these too need to be confirmed.

The different resident and seasonal migrant bird populations need to be studied in greater detail as to their occurrence and diversity, as well as improving breeding grounds and creating awareness about their significance and general conservation.

\section{Conflict of interest}

The authors declared no conflict of interest.

\section{References}

1. The Ramsar Convention Manual: a Guide to the Convention on Wetlands (Ramsar, Iran, 1971), (6th ed., 2013). 112 pages.

2. Puri, S.K. Biodiversity Profile of India. http:// ces.iisc.ernet.in/hpg/cesmg/indiabio.html

Accessed on 14.11.2020.

3. Pachuau, R. (1994) Geography of Mizoram. R.T. Enterprise, Aizawl. 22 pages.

4. Forest Survey of India, Ministry of Environment, Forest and Climate Change, Government of India (2019) India State of Forest Report. 2 Vols. ISBN 978-81-941018-0-2.

5. Champion, H.G. and S.K. Seth, (1968) A Revised Forest Types of India. Manager of Publications, Delhi, in: State of Environment Report - Mizoram (2016).

6. State of Environment Report - Mizoram (2016) Department of Environment, Forests \& Climate Change, Government of Mizoram, 352 pages.

7. National Wetland Atlas - Mizoram (2010) Space Applications Centre, Indian Space Research Organization, Ahmedabad. http://moef.gov.in/wpcontent/uploads/2019/09/

NWIA_Mizoram_Atlas.pdf . Accessed on 04/01/2021.

8. Zoological Survey of India, Kolkata (2007) State Fauna Series 14: Fauna of Mizoram, 691 pages.

9. Ali, S., and S.D. Ripley (1968) Handbook of the Birds of India and Pakistan. Oxford University Press, London.

10. Birand, A., and S. Pawar (2004) An Ornithological Survey in North-East India. Forktail, 20:15-24.

11. BirdLife International (2020) Important Bird Areas factsheet: Palak Dil. Downloaded from http:// www.birdlife.org on 16/11/2020.

12. Choudhury, A. (2006) Notable Bird Records from Mizoram in North-East India. Forktail, 22:152-155.

13. Datta-Roy, A., A. Sharma, and T.T. Azyu (2007) Kaiseitlah Conservation Area: Survey for Wildlife Values - Final Report. Samrakshan Trust and E \& F Dept, MADC, in: Ved, N. (2008) Conservation of Wildlife through Conservation Education in South Mizoram, India. Report to Rufford Small Grants 


\section{Foundation.}

14. Kasambe, R., H. Lalthanzara, and L. Sailo (2014) Bird survey in Lengteng Wildlife Sanctuary and Blue Mountain (Phawngpui) National Park, Mizoram. Buceros, 18(3):6-13.

15. Lalmuansangi, and Lalramnghinglova, H. (2014) Preliminary assessment on water quality and biodiversity in and around Palak Dil in southern Mizoram, India. Science Vision, 14(1): 39-45.

16. Lalthanzara, H. (2010) Recent status of thrreatened birds of Mizoram. Science Vision, 10(4):168-169.

17. Lalthanzara, H. and L. Sailo (2017) Avian diversity in and around Lungleng-I, Mizoram, India. International Journal of Recent Scientific Research, 8 (6):18033-18038.

18. Lalthanzara, H., and R. Kasambe (2015) Popular Birds of Mizoram. Scientific Book Centre, Guwahati. 124 pages.

19. Robertson, A. (1996) Mizoram: list of bird species observed. Unpublished report, in: Choudhury, A. (2006) Notable Bird Records from Mizoram in North-East India. Forktail, 22:152-155.
20. Sailo, Lalawmawia and H. Lalthanzara (2015) Bird diversity of Lengteng Wildlife Sanctuary, Mizoram. Science Vision, 15(2):87-96.

21. Ved, N. (2008) Conservation of Wildlife through Conservation Education in South Mizoram, India. Report to Rufford Small Grants Foundation. 12 pages.

22. Lepage, Dennis (2021) Avibase - Bird Checklists of the World - Mizoram. https://avibase.bsc-eoc.org/ checklist.jsp?region=INnemz\&list=howardmoore . Accessed on 02/01/2021.

23. Checklist of Indian Waterbirds. ENVIS Resource Partner on Avian Ecology website: http:// bnhsenvis.nic.in/Database/

IndianWaterbirds_836.aspx, updated on 13/05/2014. Accessed on 02/01/2021.

24. Department of Environment, Forests \& Climate Change, Government of Mizoram website https:// forest.mizoram.gov.in.

25. The IUCN Red List of Threatened Species website: https://www.iucnredlist.org. 